

Susann Liin

\title{
Community of Property - Back to the Roots
}

\section{Introduction}

In Estonia, the statutory matrimonial-property regime is community of property (varaühisus), according to $\$ 24$ (2) of the Family Law Act (FLA) ${ }^{*}$. According to $\$ 25$ of the FLA, the joint property (ühisvara) of the spouses comprises only objects acquired during the application of the regime, while objects acquired before marriage do not form part of it $^{*}{ }^{*}$. Therefore, this regime can be characterised as limited community of property. One of the most commonly cited traits of a community-of-property regime is that it creates a strong proprietary bond between the spouses, which obliges the partners to decide on matters related to joint property together, per §28 (1) and §29 (1) of the FLA.

Estonia's regulation was designed at the same time to protect the weaker spouse ${ }^{*}$, presuming that marriage is for life ${ }^{*}$. However, as a marital-property regime, community of property should also provide some flexibility for balancing the rights and duties of the spouses and their creditors ${ }^{*} 5$. That is not a strong point of the existing regime. The strong proprietary bond, due to which the spouses are obliged to act jointly, is so rigid and all-encompassing that spouses can hardly ever act independently. It is questionable that protection of the weaker spouse demands such extensive restrictions.

The strong proprietary bond between the spouses is expressed mainly in the fact that the spouses hold joint ownership and have to administer the joint property jointly. The two have joint ownership (ühisomand) in the sense employed in $\$ 70$ (4) of the Law of Property Act (LPA)*6. Ownership belongs to the spouses 'in undefined shares', which means that the ownership belongs to each of the spouses at the same time in its entirety*7. Since full ownership belongs to each of the spouses simultaneously, the only way of exercising their

1 Family Law Act (FLA), perekonnaseadus: RT I 2009, 60, 395; RT I, 09.05.2017, 29. Available in English at: https://www. riigiteataja.ee/en/eli/ee/507022018005/consolide/current (accessed on 4 August 2020).

2 A brief overview of the Estonian limited community of property regime is given by: S Liin, 'National Report of Estonia' in L Ruggeri, I Kunda, and S Winkler (eds), Family Property and Succession in EU Member States: National Reports on the Collected Data (Faculty of Law in Rijeka 2019) 189-90 Available in English at: https://www.euro-family.eu/news-89psefs_e_book_with_national_reports_from_28_member_states (accessed on 4 August 2020).

3 See the discussion of the draft FLA (55 SE), of 12 September 2007: XI Riigikogu stenogramm II istungjärk. Kolmapäev, 12. september 2007, kell 14:00 (transcript from 12 September 2007). Available in Estonian at: http://stenogrammid. riigikogu.ee/200709121400\#PKP-594 (accessed on 4 August 2020).

4 K Kullerkupp. 'Statutory Marital Property Law de Lege Lata and de Lege Ferenda' [2001] 1 Juridica International 81 https:// www.juridicainternational.eu/public/pdf/ji_2001_1_78.pdf (accessed on 4 August 2020).

5 Ibid, 79-80.

6 Law of Property Act (LPA), asjaõigusseadus: RT I 1993, 39, 590; RT I, 22.02.2019, 11. Available in English at: https://www. riigiteataja.ee/en/eli/ee/529082019011/consolide/current (accessed on 4 August 2020).

7 See discussion of $§ 70$ (3.3.1.1 and 3.4.1) by: P Varul, in P Varul, I Kull, V Kõve, M Käerdi, T Puri (eds), Asjaõigusseadus. I kommenteeritud väljaanne (Law of Property Act. I: Commented Edition) (Tallinn: Juura 2014). 
rights as joint owners is to do so unanimously. Neither of them may dispose of any share of the ownership independently. Accordingly, under §31 (1) of the FLA, a disposition performed by one of the spouses without consent from the other is void. The Supreme Court of Estonia has explained that this means, in addition, that acquisition in good faith is excluded ${ }^{* 8}$, which brings uncertainty for the spouses and also for third parties.

Only to meet the needs of the family may one of the spouses act alone. Generally, spouses have to exercise their rights and duties related to joint property jointly, they must even only jointly enter into transactions and act in legal disputes (see §28 (1) and §29 (1) of the FLA). Word for word, this regulation means that the spouses may only jointly possess, use, and dispose of things; transfer claims; conclude contracts; demand fulfilment of an obligation; accept declarations of intent; or act in legal proceedings and initiate them. The principle of joint administration is so comprehensive that the consent of both spouses should be obtained even if one spouse wants to file an action against the other. Following the explicit wording of §29 (1) of the FLA, Tallinn District Court issued a decision wherein it was stated that one of the spouses shall not come to court alone* 9 .

In particular, Tallinn District Court found that a husband was not permitted to file an action on his own against a third party to regain possession of an immovable in the spouses ' joint ownership, under $\$ 80$ (1) of the $\mathrm{LPA}^{* 10}$. Leaving aside even the fact that possession of that immovable had been lost in consequence of actions by his wife. In 2018, the Supreme Court annulled that judgement and formulated an exception to the principle of joint administration ${ }^{* 11}$. Although the language of §29 (1) of the FLA is straightforward, the Supreme Court ignored it and allowed the husband to come to court alone, pursuant to its finding that the aim behind §29 (1) of the FLA is to protect the spouses from misuse of matrimonial property rather than arbitrarily limit the spouses' opportunities to enter into transactions or initiate court proceedings ${ }^{{ }^{*}}$.

Considering that even the Supreme Court is trying to find ways of escaping this burdensome regulation by recourse to practical arguments while ignoring provisions that explicitly dictate otherwise, one may well find the merits of the strong proprietary bond between the spouses cast into doubt. The rigid and comprehensive regulation in the current FLA presumes that the spouses always agree and act as a single unit. Nevertheless, it is obvious that at times they will disagree. In cases of disagreement, the married person is placed in a stalemate and left only with the time-consuming option of trying to substitute for the consent of his or her spouse in court, according to §29 (3) of the FLA. It is doubtful that a stalemate situation could benefit the spouses and protect the weaker of them. Furthermore, it is hard to find justification for the restrictions being so rigid and comprehensive. The way forward should lie not in hoping the Supreme Court does not run out of practical arguments to bypass such burdensome regulation but in coming to a more systematic understanding of the regime.

In this article, the roots of community of property and the development of the regime in Estonian law since the Baltic Private Law Act (BPLA) ${ }^{*} 13$ of 1865 are analysed in conjunction with the concept of joint ownership and the principle of joint administration. Answer is sought to the questions of when the regime gained foundations of joint ownership and joint administration, where those principles come from, and whether the system has always been as rigid and comprehensive as it is now. The answers should help us understand, firstly, how it can be that community of property has stood the test of time and been applied in

8 Decision of the Civil Chamber of the Supreme Court of Estonia (CCSCd) 3-2-1-157-11, para 14; CCSCd 3-2-1-127-13, para 22; CCSCd 2-16-16048/16, paras 13-15.

9 Tallinn District Court judgement of 6 November 2017 in case 2-16-9519 - see CCSCd 2-16-9519/78, para 8.

10 Ibid.

11 CCSCd 2-16-9519/78, para 25.2.

12 Ibid.

13 When Estonia was part of Tsarist Russia, Baltic Private Law applied from the year 1865. This body of private law also applied in Estonia in 1919-1940, when Estonia was an independent state. Mentions of the Baltic Private Law Act (BPLA) refer to Volume 3 of the Baltic Provincial Code, Provincialrecht der Ostseegovernements, Dritter Teil: Privatrecht. - Liv-, Est- und Curlaendisches Privatrecht; see P Varul, 'Legal Policy Decisions and Choices in the Creation of New Private Law in Estonia' (2000) 5 Juridica International 104. The BPLA is available in German at: https://dspace.ut.ee/handle/10062/18562 (accessed on 4 August 2020), with some parts in Estonian accessible at: https://www.digar.ee/viewer/et/nlib-digar:14500/23547/ page/1 (accessed on 4 August 2020). See the further details about the BPLA provided by: M Luts, 'Private Law of the Baltic Provinces As a Patriotic Act' (2000) 5 Juridica International 157; M Luts, 'Zur Verortung des Baltischen Privatrechts (1864/65) unter den europäischen Privatrechtskodifikationen' in Rechtstransfer in der Geschichte. Internationale Festschrift für Wilhelm Brauneder zum 75. Geburtstag hg. von Gábor Hamza, Milan Hlavačka, Kazuhiro Takii (Berlin: Peter Lang 2019) 219. 
the Baltic states since the nineteenth century ${ }^{*} 14$ in such a restrictive form. Was the system different in the past, or was balance perhaps provided by better legal solutions that have since been forgotten? Understanding these historical underpinnings should show a way forward for the community-of-property regime also. Taking a few steps back can aid greatly in knowing which path should take us further in the right direction.

\section{The development of the community-of-property regime}

\subsection{The origins of the regime}

Nowadays, community of property is a widespread matrimonial-property regime - in fact, the most commonly applied system in the European Union ${ }^{* 15}$ and also employed in the French- and Spanish-influenced states of the USA ${ }^{*} 16$. Community of property as it is known today in the Western World is of Germanic origin; that is, it was instituted either directly or indirectly through conquest and colonisation by countries that can trace their regime in this family to origins among the Goths in the Germanic provinces of Europe. ${ }^{*} 17$ Systems expressing community of property do not have roots in Roman law. In contrast, Roman law featured spouses being subject to a separate-property system in the modern sense, and marriage did not affect the proprietary relations of the spouses ${ }^{* 18}$. The husband received a dowry from the wife's family, which legally belonged to him but that his wife could demand back in the event of divorce or his death ${ }^{*} 19$.

One of the earliest direct sources attesting to the existence of community of property is the Code of Euric, from fifth-century Spain ${ }^{{ }^{2} 2}$. In addition, a community-of-property regime was applied in mediaeval Franco-Belgian regions ${ }^{*}{ }^{21}$, Norway, and Sweden ${ }^{* 22}$. Community of property (Gütergemeinschaft) was applied also in mediaeval Germanic regions, was explicitly retained in the vast majority of sixteenth-century civil codes $^{*}{ }^{*}$, and continued to be the most commonly applied regime - with a range of variations ${ }^{*}{ }^{24}-$ until the entry into force of the German Civil Code (BGB) on 1 January $1900^{*}{ }^{25}$. However, the principles on which

14 T Anepaio, 'Varaühisus - kas nõukogulik igand?' (Community of Property - Is It a Remnant of Soviet Law?) (2002) 3 Juridica 193-95.

15 Community of property is used in the Netherlands and is an optional regime in Germany, but mainly it is used in countries with a Roman-law tradition, such as Belgium, France, Luxembourg, Italy, Portugal, and Spain, alongside many Eastern European countries - Bulgaria, Estonia, Hungary, Latvia, Lithuania, Poland, Romania, Slovakia, Slovenia, and the Czech Republic. See: 'Impact Assessment Study on Community Instruments Concerning Matrimonial Property Regimes and Property of Unmarried Couples with Transnational Elements, Final Report' (2010) 65-66. Available in English at: https:// op.europa.eu/en/publication-detail/-/publication/48820a62-4950-4ebb-a20c-d5bc9f35bd84 (accessed on 4 August 2020).

16 J Rieck, Ausländisches Familienrecht (Munich: C.H. Beck 2019) see 'USA', Rn. 14. Community of property ('community property') is used in nine US states: Arizona, California, Idaho, Louisiana, Nevada, New Mexico, Texas, Washington, and Wisconsin.

17 J E Sebree. 'Outlines of Community Property' (1928) 6(1) New York University Law Review 34.

18 M Kaser, Das römische Privatrecht. Abschnitt 1, Das altrömische, das vorklassische und klassische Recht (Munich: Beck 1971) 329.

19 J E Grubbs. Women and the Law in the Roman Empire: A Sourcebook on Marriage, Divorce and Widowhood (London: Routledge 2002) 95-96. DOI: https://doi.org/10.4324/9780203442524.

20 J E Sebree (n 17) 34-36.

21 See: M Vleeschouwers-Van Melkebeek, 'Separation and Marital Property in Late Medieval England and the Franco-Belgian Region' in M Korpiola (ed), Regional Variations in Matrimonial Law and Custom in Europe, 1150-1600 (Leiden/Boston: Brill 2011) 84-97. DOI: https://doi.org/10.1163/9789004211438_005.

22 See L I Hansen, 'Inheritance, Property and Marriage in Medieval Norway' and M Korpiola, 'Spousal Disputes, the Marital Property System, and the Law in Later Medieval Sweden' in C Beattie and F Stevens (eds), Married Women and the Law in Premodern Northwest Europe (Woodbridge: Boydell Press 2013) 11-52.

23 J F Harrington, Reordering Marriage and Society in Reformation Germany (CUP 1995) 194.

24 Absolute community of property (allgemeine Gütergemeinschaft), limited community of property (Errungenschaftsgemeinschaft), and community of movables (Fahrnisgemeinschaft) were used. See: E Schumann's contribution (ss $1363-557$ (III), Rn. 16-22) to M Schmoeckel, J Rückert, and R Zimmermann (eds), Historisch-kritischer Kommentar zum BGB, vol IV: 'Familienrecht'. ss 1297-921 (Tübingen: Mohr Siebeck 2018); Münchener Kommentar zum Bürgerlichen Gesetzbuch (8th edn, 2019) - Münch, preliminary remark to BGB s 1008, Rn. 1. See also: S Mai, 'Die Gütergemeinschaft als vertraglicher Wahlgüterstand und ihre Handhabung in der notariellen Praxis' (2003) 3 Zeitschrift für das Notariat in Baden-Württemberg 55 .

25 German Civil Code, 'Bürgerliches Gesetzbuch in der Fassung der Bekanntmachung vom 2. Januar 2002' (BGBl. I S. 42, 2909; 2003 I S. 738), with the most recent amendments being made pursuant to Article 1 of the law published on 12 June 2020 (BGBl. I S. 1245). Available in German at: http://www.gesetze-im-internet.de/bgb/index.html and in English at http:// www.gesetze-im-internet.de/englisch_bgb/index.html (both accessed on 4 August 2020). 
Germanic-origin community of property was initially based and the societal conditions in which the regulation was applied are considerably different from modern system.

\subsection{Community of property based on joint ownership}

In Germanic regions, marital property was, interestingly, one of the areas least influenced by Roman law and in which local customs continued to apply even after the sixteenth century brought legal standardisation $^{* 26}$. Nevertheless, Roman law did influence the concept of ownership by the spouses.

In Roman law, ownership could belong to two or more persons under the institution of co-ownership, which was called condominium ${ }^{*}$. For example, owners of separate 'substances' became co-owners of a mixture by confusio, given that the substances ended up mixed in such a way that they could not be returned to their former, known state ${ }^{*_{2} 8}$. At the same time, joint ownership did not exist. In regard of this, Ulpianus cited Celsus, who found that undivided ownership could not belong to two persons: et ait duorum quidem in solidum dominium vel possessionem esse non posse (D.13.6.5.15) ${ }^{*_{29}}$. Since joint ownership was in direct conflict with that maxim and contradicted a seemingly evident conception that only one person is able to possess something as a whole at any one time, it was considered impossible.

In mediaeval times, Germanic-origin community of property was not based on spouses having joint ownership. It was only in seventeenth-to-nineteenth-century German legal literature that the concept of joint ownership (Gesamteigentum) began being presented as a special German concept, as opposed to Roman $\operatorname{law}^{*}{ }^{30}$. One of the reasons behind the development of the concept was that community of property of the spouses did not fit into the existing Roman-law-based system, according to which the only community admitted was a co-ownership-based communion, or a corporation ${ }^{*}{ }^{31}$.

An important keyword related to the development of the concept of joint ownership is 'dominium plurium in solidum', which Justus Veracius used in 1681 to characterise the joint property of spouses as an example of dominium germanicum ${ }^{*} 32$. The first one to employ the specific notion of joint ownership (Gesamteigentum) may have been J.G. Estor, doing so in $1757^{*} 33$. W.A.F. Danz further developed the concept of joint ownership in the late eighteenth century ${ }^{*} 34$, characterising it as a case wherein the right of one of the owners extends to the whole thing, whereas a part of it is not distinguished ${ }^{*} 35$. However, in nineteenthcentury German legal literature, arguments from Roman law were already being used against joint ownership. Opponents of joint ownership considered it burdensome and impossible and to have lost its practical relevance ${ }^{*} 36$. Nowadays, joint ownership has marginalised in the country of its origin. While joint ownership is acknowledged as a theoretical concept, it indeed does not have a legal definition in the BGB. Thus it stands in contrast to co-ownership, which is defined in the BGB’s §1008. Spouses have joint ownership

26 J F Harrington (n 23) 194.

27 See: G Mousourakis, Fundamentals of Roman Private Law (Berlin: Springer 2012) 156. DOI: https://doi.org/10.1007/9783-642-29311-5.

28 Ibid, 143. See also: M Kaser, Das römische Privatrecht. Abschnitt 2, Die nachklassischen Entwicklungen (Munich: Beck 1975) 453.

29 Part of D.13.6.5.15 states: 'Where a vehicle is lent or hired to two persons, Celsus, the son, says in the Sixth Book of the Digest [...] that the entire ownership of anything cannot belong to two persons, nor can they have the entire possession, nor can one party be the owner of a portion of an article, for he can only have partial ownership of the entire article by means of an undivided share.' See P Krueger and T Mommsen (eds), Corpus iuris civilis. Volumen primum Institutiones. Digesta (Berlin: Weidmann 1932) or see S P Scott (tr), The Digest or Pandects of Justinian (Cincinnati 1932), available in English at: https://droitromain.univ-grenoble-alpes.fr/ (accessed on 4 August 2020).

30 See: S Lepsius, Gesamthand, gesamte Hand. Handwörterbuch zur deutschen Rechtsgeschichte, vol 2 (Berlin: Erich Schmidt Verlag 2020) 264-69.

31 F Limbach, Gesamthand und Gesellschaft Geschichte einer Begegnung (Tübingen: Mohr Siebeck 2016) 241-42. DOI: https://doi.org/10.1628/978-3-16-154177-3.

32 S Lepsius (n 30) 264.

33 F Limbach (n 31) 246 and 248. See also the reference in footnote 37: J G Estor, Bürgerliche rechtsgelehrsamkeit der Teutschen., Nach maasgebung der Reichs-abschiede, vol 1 (Johann Andreas Hofmann 1757) 756.

34 F Limbach (ibid) 248.

35 Ibid, 241 and 248. See the citations of W A F Danz by F Limbach, on page 248 and in footnotes 52-54.

36 F Limbach (ibid) 250-55. 
in cases of community of property, but there is no expressis verbis reference to the term in the BGB that extends it to practice ${ }^{*} 37$.

\subsection{Community of property based on joint administration of joint property}

The principle of joint administration of joint property is, interestingly, an even later addition to the Germanic-origin institution of community of property than joint ownership. An important factor in this development has been the strong influence of the principle of coverture ${ }^{*} 3$, according to which married women do not have active legal capacity.

It is worth noting that community of property has never been a statutory matrimonial-property regime in German law, which differs markedly from Estonian law in this respect. Before the BGB's entry into force, in 1900, community of property was one of the candidates for selection as the statutory matrimonial-property regime ${ }^{*} 39$; however, the regime known as Verwaltungsgemeinschaft was chosen instead, in which marital property is formed but only the husband is permitted to administer it ${ }^{*} 40$. According to the original version of the BGB, community of property could still be chosen, by means of a marital-property contract ${ }^{*}$. Nonetheless, both of the regimes had the principle of coverture as their basis. Since married women had limited active legal capacity, the husband administered joint property independently ${ }^{*}$. Consequently, there were no provisions for joint administration in the original version of the BGB; opposed to the present language in $\S \S 1450-1470$ of the $\mathrm{BGB}^{*} 43$.

Surprisingly, it was only on 1 July 1958 when $\S \S 1450-1470$ of the BGB entered into force, after largescale legal reform through which men and women were granted equal rights ${ }^{*} 44$. Those provisions were added to consider social changes and reshape community of property, which had been developed under an assumption that the man is the breadwinner of the family while women are housewives ${ }^{*} 45$. The detailed regulation in $\S \S 1450-1470$ of the BGB is designed to specify joint administration rules for each individual case, with its \$1455 itemising a list of things that one partner may do independently. Even though the provisions are precise and elaborated upon, the merits of the regulation can be doubted. In Germany, community of property is nearly obsolete in any case ${ }^{*}{ }^{6}$, and the elaborate provisions are criticised for being overly complicated. In fact, they have almost never been applied ${ }^{*} 47$.

37 The term 'Gesamteigentum' is not used in the BGB, but community of property is defined as so-called Gesamthandsgemeinschaft. See: Münchener Kommentar zum Bürgerlichen Gesetzbuch (n 24) - Münch, BGB s 1419, Rn. 1-7 and Schmidt, BGB s 1008, Rn. 1.

38 The German equivalent to coverture is Geschlechtsvormundschaft. See further information from authors such as: C Zaher, 'When a Woman's Marital Status Determined Her Legal Status: A Research Guide on the Common Law Doctrine of Coverture' (2002) 94(3) Law Library Journal 459. About coverture in German regions, discussion is offered by: S Ogilvie, 'Married Women, Work and the Law: Evidence from Early Modern Germany' in C Beattie and M F Stevens (eds), Married Women and the Law in Premodern Northwest Europe (Boydell Press 2013) 213-40.

39 It was primarily Georg Beseler and Otto von Gierke who supported community of property. See: Historisch-kritischer Kommentar zum BGB (n 24) - Schumann, ss 1363-557 (III), Rn. 91-94. See the original version of the BGB also (the 1900 BGB), available in German at: http://www.koeblergerhard.de/Fontes/BGBDR18961900.htm (accessed on 4 August 2020).

40 See sections 1363-425 of the 1900 BGB; Historisch-kritischer Kommentar zum BGB (n 24) - Mayenburg, ss 1363-557 (III), Rn. 6-15.

41 See sections 1437-518 of the 1900 BGB; Historisch-kritischer Kommentar zum BGB (n 24) - Schumann, ss 1363-557 (III), Rn. 18.

42 A husband had to have his wife's consent only for transactions with immovables, to dispose of the property as a whole, and for some gifts (ss 1444-46 of the 1900 BGB).

43 It was stated in $\$ 1472$ of the 1900 BGB that spouses have to manage joint property jointly after the divorce until the division of joint property was complete; nevertheless, there were no provisions as would have specified this statement.

44 See the draft of law granting men and women equal rights: 'Gesetz über die Gleichberechtigung von Mann und Frau aufdem Gebiete des bürgerlichen Rechts' Bundesgesetzblatt, part I, no. 26 (21 June 1957) 609 ff, available in German at: http:// www.bgbl.de/xaver/bgbl/start.xav?startbk=Bundesanzeiger_BGBl\&jumpTo=bgbl157s0609.pdf (accessed on 4 August 2020). For further details about historical development, consult: S Mai (n 24) 55-71.

45 B Rešetar, 'Matrimonial Property in Europe: A Link between Sociology and Family Law' (2008) 12(3) Electronic Journal of Comparative Law. https://www.ejcl.org/123/art123-4.pdf (accessed on 4 August 2020).

46 See: Münchener Kommentar zum Bürgerlichen Gesetzbuch (n 24) - Münch, preliminary remark to BGB s 1415 Rn. 15 and 19; S Mai (n 24) 56.

47 Ibid. 


\section{The development of community of property in Estonian law}

\subsection{General notes on the institution under Estonian law}

At the beginning of the twentieth century, community of property was a widespread matrimonial-property regime in Estonia, one that was already familiar from the nineteenth century's Estonian and Livonian peasant laws but also regulated by the BPLA ${ }^{*} 48$. Community of property was the matrimonial-property regime in force for those subject to the city law of Livonia and of Narva and applicable to Livonian non-parish priests $^{*} 49$. With marriage, the property of the husband and of the wife became joint property of the spouses, per sections $67-68,79-80$, and 109 of the BPLA.

The BPLA was followed by a draft for a Civil Code of Estonia (1940 CC) ${ }^{*}{ }^{50}$, according to $\S \S 352-386$ of which the spouses could choose either absolute or limited community of property via contract as their marital-property regime. The statutory matrimonial-property regime set forth, however, was community of accrued gains ${ }^{*}{ }^{1}$.

During the Soviet occupation, at first the Russian Civil Code (RCC) ${ }^{*}{ }^{5}$ was applied, from 1 January 1940 to 5 December 1941 and again from 7 September $1944^{*} 53$. At the start of 1965, the Estonian Soviet Civil Code (SCC) ${ }^{*} 54$ entered into force. Meanwhile, the Russian Code of Marriage, Family and Guardianship $\left(\right.$ RCMFG) ${ }^{*} 55$ from 1 January 1941 and the Estonian Soviet Marriage and Family Code (MFC) from 1 January 1970 regulated family law ${ }^{*} 56$. Community of property was the statutory matrimonial-property regime throughout the Soviet occupation ${ }^{*} 57$, but it has persisted ever since too, during the application of the Family Law Act of $1995^{*}{ }^{58}$ and presently, according to $\$ 24$ (2) of the FLA.

In the early 2000s, an attempt was made to replace community of property as the statutory matrimonial-property regime with community of accrued gains as articulated in the $1940 \mathrm{CC}$. However, the attempt was unsuccessful ${ }^{*} 59$. Community of property had become so customary that changing it had not even been discussed on a larger scale ${ }^{*} 60$, and the plan to replace it drew opposition from society. Interest groups

48 T Anepaio (n 14) 193-94.

49 Ibid, 193-94, for further discussion pertaining to the particular regions in which community of property regime applied.

50 The draft for a Civil Code of Estonian from 1940 is available in Estonian as Tsiviilseadustik (Civil Code Act) (Tartu Ülikool 1992). https://dspace.ut.ee/handle/10062/26808 (accessed on 4 August 2020). The preparation of Estonia's own civil code began in the 1920s. While the civil code was complete in 1940, it was never adopted, because of the Soviet occupation. The 1940 CC was largely based on the norms of the BPLA, Germany's BGB, the Swiss Civil Code, and the Austrian Civil Code. See: P Varul (n 13) 108.

51 See: J Uluots, Seletuskiri tsiviilseadustiku 1935. a. eelnõu nelja esimese raamatu juurde (Explanatory Notes to the First Four Books of the Draft Civil Code of 1935) 50. Available in Estonian at: http://www.digar.ee/id/nlib-digar:46225 (accessed on 4 August 2020).

52 The Russian Civil Code, including amendments until 15 November 1940: VNFSV tsiviilkoodeks: muudatustega kuni 15. novembrini 1940 (ENSV Kohtu Rahvakomissariaadi kodifikatsiooni-osakond; Tallinn: Riigi Trükikoda 1940).

53 See P Varul (n 7) - Kull, on part 1, general part, 6.3.

54 The Estonian Soviet Civil Code is available as Eesti NSV tsiviilkoodeks, ENSV ÜT 1964, 25, 115 in Estonian at: https://www. digar.ee/arhiiv/nlib-digar:386218 (accessed on 4 August 2020). See further discussion of the reforms during the time of Soviet occupation: M Luts-Sootak and H Siimets-Gross, Eesti õiguse 100 aastat (100 Years of Estonian Law) (Tallinn: Post Factum 2019) 98-103.

55 The Russian Code of Marriage, Family and Guardianship's official text, including the amendments until 25 August 1945 and an annex of systematised materials, is available as: VNFSV abielu, perekonna ja eestkoste seaduste koodeks. Ametlik tekst muudatustega kuni 25. augustini 1945. a. ühes paragrahvide järgi süstematiseeritud materjale sisaldava lisaga (Tartu: RK 'Teaduslik kirjandus’ 1946). Available in Estonian at: https://www.digar.ee/arhiiv/nlib-digar:215351 (accessed on 4 August 2020).

56 The Estonian Soviet Marriage and Family Code is available as: Eesti NSV abielu-ja perekonnakoodeks (Tallinn: Eesti Raamat 1969), in Estonian at: https://www.digar.ee/arhiiv/nlib-digar:214888 (accessed on 4 August 2020).

57 Property acquired during marriage was joint property of the spouses, per $\S 10$ of the RCMFG and §20 of the MFC.

58 Family Law Act of 1995, perekonnaseadus. RT I 1994, 75, 1326; RT I 2009, 60, 395 was in force from 1 January 1995 to 30 June 2010. The text is available in Estonian at: https://www.riigiteataja.ee/akt/13249859 (accessed on 4 August 2020). According to $§ 14$ (1) of the 1995 FLA, property acquired during marriage was the joint property of the spouses.

59 A draft of the Family Law Act (55 SE) was submitted to the parliament in 2007, but it was never adopted. See the draft and the explanatory notes to it, available in Estonian at: https://www.riigikogu.ee/tegevus/eelnoud/eelnou/982033c7-c2e12ce6-0479-ef2bf925488b/Perekonnaseadus (accessed on 4 August 2020).

60 K Kullerkupp (n 4) 80. 
were against the amendment because they concluded that the reform would harm the economically weaker spouse $^{* 61}$. In legal literature, the institution of community of property was defended with arguments relying on tradition. It was said that criticising community of property for being a remnant of Soviet law is unwarranted because community of property was already acknowledged in the Baltic states in the final part of the nineteenth century ${ }^{*} 62$. Although the latter may be true, community of property was rather different back then, because of the principles on which it was based. We examine that part of the picture next.

\subsection{Joint-ownership-based community of property in Estonian law since the nineteenth century}

Joint ownership by the two spouses was already under discussion in the nineteenth century in Estonian legal literature, just as in Germany. Interestingly, while joint ownership was a familiar concept in Estonia, it was not actually applied until quite recently.

According to $\S 68$ and $\S 80$ of the BPLA, the marital property of the spouses, who were in community of property, was called joint property. This does not mean that the two had joint ownership, however. The ways in which ownership could belong to more than one person were regulated by the BPLA's §927. This stated that a single thing could belong to many persons undivided - not in real parts, however, but in legal shares - in such a way that only the legal position of the owners is divided. Remark 3 on §927 of the BPLA made clear that only co-ownership was intended. The remark specified that a type of shared ownership wherein many persons own the same thing such that it belongs to all of them in its entirety - so-called joint ownership (Gesammteigenthum) - was not acknowledged ${ }^{* 63}$.

The author of the BPLA, F.G. Bunge, found that community of property of spouses is based on German theory of joint ownership neither in Estonian nor in Livonian law ${ }^{* 64}$. C. Erdmann found joint ownership to be excluded per the BPLA and explained the nature of $\S 927$ of the BPLA with reference to Miteigenthum and Condominium, which are the German- and Roman-law equivalents to co-ownership, not joint ownership ${ }^{* 65}$. C. Erdmann criticised joint ownership in connection with a conclusion that the concept's very definition is in direct contradiction with the exclusive nature of ownership ${ }^{* 66}$. Accordingly, although the spouses had joint property, they were co-owners. Joint ownership was deliberately not specified in the BPLA.

According to $\S \S 352-386$ of the 1940 CC, community of property could be chosen by marital-property contract. Spouses had joint property, but the concept of joint ownership was not used. While co-ownership was regulated in $\S \S 930-940$ of CC 1940, there was no reference to joint ownership, either in the act or in its explanatory notes ${ }^{*} 67$. Instead, $\S 940$ of CC 1940 stated that the regulation of co-ownership applies meaningfully also to joint property, to the extent that the regulation pertaining to joint property did not provide

61 The criticism raised is documented in the transcript of the draft's discussion on 12 September 2007: XI Riigikogu stenogramm II istungjärk. Kolmapäev, 12. september 2007, kell 14:00 (n 3). See also the 19 February 2008 press release from the Estonian Women's Association Roundtable (Eesti Naisteühenduste Ümarlaud) and a reference to an analysis available in Estonian at: http://www.enu.ee/enu.php?keel=1\&id=4\&uid=56 (accessed on 4 August 2020).

62 T Anepaio (n 14) 193-95.

63 Remark 3 on $\S 927$ of the BPLA stated: 'Ein solches Eigenthum Mehrerer an derselben Sache, vermöge dessen jedem von ihnen die Sache ganz gehört, ein sog. Gesammteigenthum, wird gesetzlich nicht anerkannt.'

64 F G von Bunge, Das liv- und esthländische Privatrecht. 1. Theil, Die Einleitung, das Personen-, Sachen- und Forderungenrecht enthaltend. 2. sehr vermehrte und verbesserte Auflage (Reval: F Kluge 1847) 201. Available in German at: http:// hdl.handle.net/10062/6784 (accessed on 4 August 2020).

65 C Erdmann, System des Privatrechts der Ostseeprovinzen Liv-, Est- und Curland. Band. 2. Sachenrecht (Riga: N. Kymmel 1891) 21 and 23. Available in German at: http://hdl.handle.net/10062/17599 (accessed on 4 August 2020).

66 Ibid, 21 and 23.

67 J Uluots, 'Seletuskiri tsiviilseadustiku 1936. a. eelnõu juurde' (Explanatory Notes to the Draft Civil Code of 1936) 37 and 55. Available in Estonian at: https://dspace.ut.ee/handle/10062/48579 (accessed on 4 August 2020). Mention is made only that the regulation of co-ownership can be applied in the event that there is joint property, and the terms are not further analysed. However, the concept of ühisomandus is briefly mentioned as an assumption in §282 of the 1935 version of the $1940 \mathrm{CC}$ and $\S 276$ of the 1936 version of it. The former is available (in Estonian) as: Tsiviilseadustiku 1935. a eelnõu. Tallinn. Koostatud kohtuministeeriumi kodifikatsiooni-osakonna juures asuva tsiviilseadustiku-komisjoni poolt http:// www.digar.ee/id/nlib-digar:258860. The latter, also in Estonian, can be found as: Tsiviilseadustiku 1936. a eelnõu. Eesti. Kohtuministeerium. Kodifikatsiooni osakond. Tsiviilseadustiku komisjon https://www.digar.ee/arhiiv/nlib-digar:259474 (both accessed on 4 August 2020). 
otherwise. Therefore, although the spouses had joint property, they were co-owners. Rather than articulate joint ownership, the 1940 CC employed provisions dealing with co-ownership.

It was only with the era of Soviet occupation that joint ownership by the spouses became acknowledged. Even then, there was significant terminological confusion at first. According to \$10 of the RCMFG, the objects acquired during marriage were joint property of the spouses; nevertheless, when one considers the provisions of the RCC that regulated property law at that time, doubt emerges as to whether the spouses having joint property meant that, concurrently, they had joint ownership. Comparison of the Estonian translations of the RCC from 1940 and 1952 reveals that the notions of co-ownership and joint property were used synonymously at times and that the adjustments to the Estonian translation of the act were incoherent ${ }^{* 68}$.

Terminological developments were notable only after a textbook on Russian civil law was translated into Estonian in 1947. Although §§ 61-65 of the RCC continued to use only the term 'co-ownership', this textbook in translation already mentioned joint ownership as a modified form of co-ownership, one found among spouses and the members of collective farms ${ }^{*} 69$. In 1955, E. Laasik most likely became the first in Estonia to suggest drawing a distinction between co-ownership and joint ownership as different types of shared ownership. This was done in an article ${ }^{*} 70$ referenced in a later book by P. Kask ${ }^{*} 71$ : E. Laasik criticised the Estonian translation of the Russian law textbook and found that co-ownership should not be used as a general gloss for ownership that belongs to two persons concurrently ${ }^{*} 72$. He reasonably pointed out that using the concept of co-ownership simultaneously in both a broader and a narrower sense causes confusion. He suggested that a new term, 'shared ownership' (ühine omand), should be brought into use as a general one covering both co-ownership (kaasomand) and joint ownership (ühisomand) ${ }^{*} 73$.

The proposal by E. Laasik seems to have been influential, given that when the SCC entered into force, at the start of 1965, joint ownership had a legal definition for the first time in Estonian legal history. Section 120 (1) of the SCC listed persons who could hold shared ownership, and §120 (2) of the SCC distinguished between co-ownership, which belongs to persons in particular defined legal shares, and joint ownership, wherein the shares of the owners are undefined. This landmark was followed five years later by the entry into force of the MFC, §20 (1) of which stated clearly that the property spouses acquire during their marriage is in their joint ownership. A distinction between co-ownership and joint ownership was expressed also in a textbook on Soviet civil law from $1971^{*} 74$, which explained that spouses could have joint ownership in the sense of $\S 20$ of the MFC and members of the collective farms in the sense of $\S 129$ of the $\mathrm{SCC}^{*} 75$. The present terms in $\S 70(1-3)$ of the LPA were based on $\S 120$ of the $\mathrm{SCC}^{*} 76$, with minor revisions. After Estonia regained independence, on 20 August 1991, the existing property law was not changed; only Soviet-specific regulation was omitted in the course of the civil-law reform that followed ${ }^{*} 77$. However, provisions pertaining to community of property were nonetheless changed to create a clearer distinction between the relevant ownership and property concepts ${ }^{*} 78$. Thus it becomes clear that the fact that community of property existed

68 According to $\S 63$ of the RCC, co-owners were liable for obligations related to joint property (1940) or co-ownership (1952). At the same time, according to §279 of the RCC, partners had co-ownership (1940) or joint property (1952). See the 1940 version of the RCC (ibid) and the 1952 version, the civil code that was applied in the territory of the Estonian SSR, inclusive of amendments, until 1 January 1952, with an annex of systematised materials: Eesti NSV territooriumil kehtiv tsiviilkoodeks: ametlik tekst muudatustega kuni 1. jaanuarini 1952, ühes paragrahvide järgi süstematiseeritud materjale sisaldava lisaga (Tallinn: Eesti Riiklik Kirjastus 1952).

69 M M Agarkov and D M Genkin (eds), Tsiviilõigus. I (Civil Law I) (A Randalu and A Sermat (tr), Tartu: Teaduslik Kirjandus 1947) 319, 362, and 363.

70 E Laasik, 'Mõningaid eestikeelse juriidilise terminoloogia küsimusi' (Some Questions Pertaining to Estonian Legal Terminology) (Tartu Riikliku Ülikooli toimetised, Õigusteaduskonna töid. Vihik 39 (Publications of Faculty of Law. Booklet 39); Tallinn: Eesti Riiklik Kirjastus 1955) 162-63. Available in Estonian at: http://hdl.handle.net/10062/36440 (accessed on 4 August 2020).

71 See P Kask, 'Asjaõigusliku mõtte arengust Eestis: kriitiline analüüs' (The Development of Legal Thinking Related to Property Law in Estonia: Critical Analysis) (Tartu: Greif 2011) 81.

72 E Laasik (n 70) 162-63.

73 Ibid, 163.

74 J Ananjeva, P Kask, V Kelder, Nõukogude tsiviiloõigus: üldosa (Soviet Civil Law: General Part) (Tallinn: Valgus 1971) 281-83.

75 Ibid, 283 and 293.

76 See: P Varul's LPA commentary (n 7) on s 70, 2.

77 P Varul, 'Omand: üldsätted' (Ownership: General Provisions) [1993] 4 Juridica 78-80.

78 For further details of the changes connected with the concept of joint property, see K Kullerkupp, T Uusen-Nacke, K KerstnaVaks, 'Ühine vara, eraldi võlad: võlausaldajate nõuete rahuldamine abikaasade ühisvara arvel' (Joint Property, Separate Debts: Satisfaction of Creditors' Claims on Account of Spouses' Joint Property) [2016] 7 Juridica 440-43. 
and marital property was called joint property already in the nineteenth century does not mean that spouses have had joint ownership since the 180os. Spouses did not have joint ownership in Estonian law before the SCC and MFC entered into force (1965 and 1970, respectively).

\subsection{Community of property based on joint administration of joint property in Estonian law since the nineteenth century}

In a parallel with developments in German law, the principle of joint administration of joint property does not have long traditions in Estonian law. Initially, the administration of joint property in cases of community of property relied likewise on the principle of coverture.

As noted above, under the BPLA, community of property applied where the city law of Livonia or Narva was applied and in cases involving Livonian non-parish priests ${ }^{*} 79$. With marriage, the husband became the guardian of the wife, according to §11 of the BPLA. Therefore, even in cases of community of property, the husband administered joint property alone, in general, in accordance with §71, §82, and §109 of the BPLA.

The amendments produced in the course of the discussions about drafting an Estonian Civil Code, in 1923-1940, show development of increasing levels of equality of husband and wife. One of the most important changes relative to the BPLA's terms was the draft material's abolition of universal coverture ${ }^{* 80}$. One key cause for this was the application of $\S 6$ of the Constitution of Estonia of $1920^{*} 81$, which stated that men and women have equal rights ${ }^{*} 82$. Another reason was agitation by women's rights organisations, who made numerous statements, starting in 1923, in which they demanded the abolition of coverture and establishment of equality of men and women. ${ }^{*} 83$ These culminated in amassing 31,000 protest letters in $1930^{*} 84$.

Per the 1926 draft version of $1940 \mathrm{CC}^{* 85}$, only the husband could administer marital property. This was held to be true under a statutory matrimonial-property regime of so-called varaühendus and in cases of community of property alike ${ }^{*} 86$. However, the versions of 1935 and 1936 of 1940 CC were already more liberal. In place of the so-called varaühendus, community of accrued gains became the statutory matrimonial-property regime ${ }^{*} 87$, with husband and wife having equal rights to decide over questions related to family life, according to the general provisions. Nevertheless, in cases of disagreement, the husband's vote on the matter was to prevail, or, alternatively, the matter would need to be decided by the courts ${ }^{*} 88$. In cases of community of property regime, the principle that the husband administered joint property alone was not abandoned, but spouses were now to dispose of immovables jointly and to decide together on matters falling outside ordinary administration ${ }^{*} 89$. The same extent of joint administration was the maximum limit set forth in the final version of $1940 \mathrm{CC}^{*}{ }^{\circ}$.

$79 \quad$ T Anepaio (n 14) 194.

80 K Kiirend-Pruuli, 'Abikaasade isiklike suhete õiguslik korraldus Eesti esimesel iseseisvusperioodil: tee kaheliikmelise parlamendi suunas' (The Regulation Pertaining to the Personal Relations of the Spouses in the First Period of Independence of Estonia: A Way toward a Two-Member Parliament) Õpetatud Eesti Seltsi Aastaraamat 2017/IX (Tartu 2018) 205 and 223. Available in Estonian at: http://oes.ut.ee/wp-content/uploads/2017_9_Kiirend-Pruuli.pdf (accessed on 4 August 2020).

81 The Constitution of Estonia of 1920. Eesti Vabariigi Põhiseadus 1920. - RT 9.8.1920, 113/114, 243. Available in Estonian at: https://www.riigiteataja.ee/failid/1920.html (accessed on 4 August 2020).

82 For further information, see also: K Kiirend-Pruuli (n 80) 208-209.

83 See further information about various pleas by the women's rights organisations in: K Kiirend-Pruuli (n 80) 213-16.

84 T Anepaio (n 14) 193. See also: T Günthal, 'Nõupidamine Perekonnaseaduse eelnõu asjus' (Discussion about the Draft Family Law Act) [1932] 7 Õigus 334, n 4. Available in Estonian at: https://www.digar.ee/arhiiv/nlib-digar:26861 (accessed on 4 August 2020).

85 The 1926 version of the 1940 CC. Tsiviil seadustik: üldosa ja perekonna õigus. Tallinn: Kohtuministeeriumi kodifikatsiooni osakond, 1926. Available in Estonian at: https://dspace.ut.ee/handle/10062/50914 (accessed on 4 August 2020).

86 The statutory matrimonial-property regime of so-called varaühendus was based solely on coverture, regulated in $\S \S 380-404$ of the 1926 version of the 1940 civil code. Absolute and limited community of property could be chosen via marital-property contract, per $\S \$ 413-37$, but the husband administered joint property alone in that case too. See $\S 415$ and $\S 435$.

87 See $\$ 292$ of the 1935 version of the $1940 \mathrm{CC}$ and $\S 278$ of the 1936 version of it.

88 See §264 of the 1940 civil code’s 1935 version and §266 of its 1936 version.

89 See $\$ 334$ and $\S 335$ of the version of the 1940 CC from 1935 and $\S 336$ and $\S 337$ of the one from 1936.

90 See the 1940 version of the 1940 CC as reproduced by: L Saarniit, 'Tsiviilseadustik' (1992). Available in Estonian at: https:// dspace.ut.ee/handle/10062/26808 (accessed on 4 August 2020). 
During the Soviet occupation, the equality of men and women was explicitly mentioned in $\S 122$ of the Constitution of SSSR and $\S 94$ of the Constitution of Estonian SSR ${ }^{*}$, and it was further emphasised in $\S 9$ of the RCMFG. However, the principle of joint administration was explicitly stated in Estonian law only after the MFC entered into force, in 1970. According to §21 (1) of the MFC, spouses had to possess, use, and dispose of objects in their joint ownership in mutual agreement. This provision was the source for the provisions of the FLA of $1995^{*}{ }^{* 2}$, wherein a similar principle was stated in $\S 17(1-2)$. However, the principle of joint administration remained quite general and was never as rigid and comprehensive as what is found in the FLA now in force.

Before the current FLA became valid, the principle of joint administration covered only exercising the right of ownership together. Spouses had to possess, use, and dispose of jointly owned things together. It was only in 2010 that $\$ 29$ (1) of the FLA entered into force and, accordingly, spouses were further obliged to conclude contracts as a pair and go to court together. The role model for such extensive regulation was not earlier Estonian law but $\$ 1450$ of the German BGB, where almost identical wording is used ${ }^{*} 93$.

The foregoing discussion shows that joint administration of joint property has not been a principle with a long history in Estonian law. It was first applied in 1970, when the MFC entered force, and even then applied only to exercising the right of ownership. It is only for the last 10 years that spouses have been explicitly obliged to conclude contracts and go to court jointly - since the present FLA entered into force.

\section{Conclusions}

\subsection{The past}

Community of property, today a widely applied matrimonial-property regime, is of Germanic origin, and its roots extend back to the mediaeval era. In Estonia, it has been applied at least since the nineteenth century, and it has traditionally been a statutory matrimonial-property regime. However, community of property has endured for centuries not because the problems related to joint ownership and joint administration had better legal solutions. It endured because it was a different and less restrictive system at first, one based on coverture and co-ownership.

Community of property was not initially based on spouses having joint ownership. Joint ownership is a specific German concept that was developed only in the eighteenth century and criticised from the beginning on the basis of arguments from Roman law. In Estonian law, joint ownership has been a recognised concept since the nineteenth century, but it was deliberately left out of the BPLA and the draft of 1940 CC because of criticism levelled against it in legal literature. Only after the 1950s was joint ownership transplanted to the Estonian legal landscape, with inspiration from a translation of a Russian textbook on civil law and only in 1970, when it was explicitly stated that spouses have joint ownership. Joint property of the spouses did not presume the spouses also having joint ownership. Community of property may be a regime with mediaeval roots, but joint ownership in Estonia is a relic of Soviet law.

In addition, community of property was not based on the principle of joint administration of joint property initially. Until the twentieth century, the foundation for community of property was the assumption that, for reason of coverture, only the husband as head of household may administer joint property. It was only in the middle of the last century that the principle of joint administration was developed, in an attempt to merge the equality of men and women into the existing system of community of property. In German law, $\S \S 1450-1470$ of the BGB were added in 1958. Those provisions contained very specific and comprehensive rules pertaining to joint administration of joint property. That was in contrast with the Estonian law of the time, which contained little more on the matter than a general rule stating that spouses have to exercise the

91 See: abstracts from the constitutions in the RCMFG text (n 55) 3. The material is available in Estonian at: https://www. digar.ee/arhiiv/nlib-digar:215351 (accessed on 4 August 2020).

92 See: K Kullerkupp (n 4) 78.

93 Section 29 (1) of the FLA states: 'If spouses administer their joint property jointly, they may enter into transactions with respect to the property and conduct legal disputes relating to the property only jointly or with the consent of the other spouse' (emphasis added). Section 1450 (1) of the BGB states that '[i]f the marital property is jointly managed by the spouses, the spouses are in particular entitled only jointly to dispose of the marital property and to conduct legal disputes that relate to the marital property' (emphasis added). One difference is that the BGB refers to disposition, not obligatory transactions. 
right of ownership jointly. Nevertheless, in 2010, when today's FLA entered into force, Estonia caught up with the amendments made in Germany in 1958. On the example of $\$ 1450$ of the BGB, §29 (1) of the FLA was implemented, which additionally obliged spouses to conclude contracts jointly and act in court jointly.

Therefore, one can conclude that the strong proprietary bond between spouses with regard to community of property was not based on rigid and comprehensive regulation stretching back to mediaeval times. Not equality between men and women but coverture formed the foundation for community of property for centuries, and joint property of the spouses did not necessarily mean joint ownership by the spouses. Regulation in this regard has been especially rigid and all-encompassing in Estonian law only since 2010.

\subsection{The future}

The fact that community of property has been applied against highly varied social backgrounds historically makes it questionable that a functioning yet specific system can be retained as the society and, therefore, the key principles of the regime fundamentally change. In Estonia, a long tradition of community of property being enshrined as a statutory matrimonial-property regime is coupled with reluctance to even discuss changing it, so a solution is required. It seems unfruitful to wait until the burdensome nature of the regulations and their lack of legal clarity force the Supreme Court to make further exceptions in reliance on practical arguments, irrespective of provisions that explicitly contradict those exceptions.

One option might be to take the German approach. Instead of providing a summary of German law in the FLA, the whole German system could be transplanted to Estonian law, including an analogue to $\$ 1455$ of the BGB, which explains the cases in which spouses may act independently. Stating clear exceptions to the general principle that spouses have to act together would render the rigid system more flexible. However, this still would seem to be a step in the wrong direction: even from the outset, $\S \S 1450-1470$ of the BGB were not good role models for Estonia. In Germany, these provisions have faced criticism for being overly complicated and have hardly ever been applied, ever since their adoption. Community of property and the equality of men and women are simply not compatible. Comprehensive rules on joint administration just end up making for an artificial and casuistic system. Instead, a few steps back could lead the way forward to a more liberal regime, one that would still protect the weaker spouse.

From a look at the roots of community of property, it is evident that problems with complicated and comprehensive restrictions were avoided because joint ownership was not actually applied and joint property was administered by only one of the spouses.

Firstly, the criticism of joint ownership as an impossible concept in both Roman law and German legal literature can be considered. Since joint property does not presume joint ownership, why not apply regulation pertaining to co-ownership instead or make the most of the reference to co-ownership rules in $\$ 70$ (6) of the LPA? It makes little difference whether spouses have, for example, a car in their co-ownership or joint ownership. Although, unlike joint owners, co-owners can dispose of their legal share in the ownership individually, according to $\$ 73$ (1) of the LPA, it is rather unlikely that a legal share in the ownership of, for instance, a car would be marketable. Even if one spouse were to dispose of his or her share purely to annoy the other, the weaker spouse can still be reasonably protected with a claim of compensation. To protect the weaker spouse, it is crucial that the value of joint property be retained until its division, whereas preservation of each individual object does not have any added value. The family home might constitute an exception, given that a legal share of ownership to an immovable is marketable and a family home holds emotional value. However, even for that or to preserve other items with emotional value, the concept of joint ownership still is not needed. The individual-specific right of disposition by one of the spouses could be limited for those items, similarly to what is done by the provisions that already address family homes in $\S 27$, §30 (2), and §41 (2) of the FLA.

Secondly, the time has come to acknowledge that it is impractical to force spouses to act as a single unit when administering joint property. It is obvious that spouses disagree at times and that leaving them in a stalemate position does not protect the weaker of them. Instead, the freedom of the spouses to act independently should be increased, to make the regime more similar to the one that endured for centuries. Restricting the right of disposition while specifying the liability of the spouses, if needed, would be enough to protect the weaker spouse. In its current wording, §29 (1) of the FLA only causes confusion in court proceedings and leaves an incorrect impression that a married person cannot conclude valid contracts alone. 